\title{
THE TROPICAL RAIN FOREST NEAR ITS NORTHERN LIMITS IN VERACRUZ, MEXICO: RECENT AND EPHEMERAL?*
}

\begin{abstract}
Alan Graham**
The Tropical Rain Forest is frequently characterized as a stable community remaining virtually unchanged during much of Cenozoic time (Ashton, 1969; Brieger, 1969; Richards, 1964). Another feature commonly acknowledged, occasionally by the same author, is that almost nothing is known about the geologic history of the community. Corner (1958) states that "Still less is known of the geological history of the Amazon and Congo forests than the Indo-Malavsian forest, except that they must have extended in modern dress since Eocene times". Recent evidence documents considerable climatic and sea level fluctuation in equatorial regions during the Quaternary (Bartlett and Barghoorn, 1973). These environmental changes are reflected in pollen diagrams (van der Hammen and González, 1960) and in relict distribution patterns of plant. (Vuilleumier, 1971) and animals (Haffer, 1970; Vanzolini, 1973). New evidence is now available also demonstrating considerable alteration in distribution and generic composition in the late Tertiary.

An assemblage of 110 identified fossil spores and pollen has been recovered from the Paraje Solo Formation, south-coastal Veracruz. The Paraje Solo is of uppermost Miocene age, based on benthic and planktonic foraminifera in the underlying (Concepcion Superior) and overlving (Agueguexquite) formations. The pollen and spore assemblage thus represents remnants of a vegetation growing in south-coastal Veracruz and along the eastern escarpment of the Sierra Madre Oriental approximately 10-12 million years ago. The arrangement of these taxa into paleocommunities is facilitated by the recent Tipos de Vegetacion de la Republica Mexicana, and a summary of the Veracruz flora by Gomez-Pompa (1973). Comparison between the modern and upper Miocene communities reveals some some similarities and other distinct differences, especially with reference to the Tropical Rain Forest.

Lignites are deposited in warm-temperate to tropical coastal brackish environments where mangroves are frequently the dominant vegetation. Pollen of Rhizophora is abundant in Paraje Solo sediments, reaching 96\% at one locality. Another mangrove, Lagunculuria. is also present along with several genera associated with mangrove communities (Hibiscus, Sapium. Mimosa. Ludwigia, Utricularia). On upland slopes bordering the lowlands, at elevations between $1000-2000 \mathrm{~m}$, scattered remnants of an

* Roseareh for this stuht was supperted ln NSF gramts 6;-567l and (;B-11862. Paper presented at the

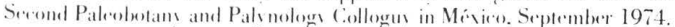

** Department of Beolegieal Se ieners. Kent State L nisersils. Kent. Ohio. I. S. A.
\end{abstract}

Graham A. 1977. The tropical rain forest near its northern limits in Veracruz, Mexico: Recent and ephemeral? Boletín de la Sociedad Botánica de México 36: 13-19. 
BOLETIN DE LA SOCIEDAD BOTANICA DE MEXICO No. 36, 1977

oak-Liquidambar forest reflect former widespread occurrence of the Bosque Caducifotio (Deciduous Forest) in Veracruz. Both the dominants (Qucreus. Liquidambar) and numerous associated genera have been recovered from the Paraje Solo Formation (Psiloum Selaginella. Lucopodium. Alsophila. Crathea. Podocarpus. Pinus. Clevera. Mirica. Hampera. Hedvosmum. Eugenia/Mvrcia. Guarea, Mex, Justicia. Dichapetalum. Struthanthus, Juglans, Meliosma. Populus. Ulmus. Iresine. Alchornea. Engelhardia. Tournefortia. Chamaedorea).

Between the coastal mangroves and upland deciduous forests are extensive areas of suothern Veracruz occupied by remnants of the Selva Alta Perennifolia (Tropical Rain Forest). According to Gomez-Pompa (1973), "This is the tallest vegetation type in Veracruz, where it grows in the more humid, warm areas of the state with precipitation from 2,500-5,000 $\mathrm{mm}$ or more per year and with few if any dry months. One of its characteristics is that $80 \%$ or more of the component species are evergreen, or at least they do not follow a definite pattern of leaf fall at one time. This vegetation type is one known as "tropical rain forest", "rain forest", "wet tropical forest", "evergreen tropical forest" or combination of these names. In Veracruz this type of vegetation is found at the lowland flatlands at the base of mountains and at the southern end of the state. In the Sierra de los Tuxtlas it occupies a great portion of the slope at altitudes below $700 \mathrm{~m}$." On the basis of criteria mentioned by Gómez-Pompa (1973), this community qualifies at Tropical Rain Forest as defined by Richards (1964) and is so maped on the recent Tipos de Vegetación.

Since this community occurs marginal to the depositional basin its presence should be evident in the fossil assemblage. Pollen of 23 genera found in rain forest vegetation have been recovered. Close scrutiny of these genera show, however. that (a) most are wide-ranging and extend into other types of vegetation (Lvoopodium. Podocrarpus. Chamaedorea, Alchornea, Tetrorchidium, Casearia, Bursera, Iresine, Hibiscus, Cupania, Sapium, Guarea, Hampea, Cedrela, Faramea, Paullinia, Spathiphvllum), and (b) of the seven dominants in the modern Veracruz rain forest (Trrminalia. Calophyllum, Dialium, Bernoulia, Brosimum, Ficus, and Pseudolmedia) only one (Terminalia) has tentatively been identified in the microflora. The significance of the latter is difficult to assess since pollinating mechanisms have not be $4 \mathrm{n}$ studied critically for any of the Veracruz species. Pollen of Ficus would not be expected in the microflora because of the small amounts produced and obligatory inseet pollination. However Brosimum alicastrum Sw. and Pseudolmedia oxyphyllaria Donn. Smith are apparently wind pollinated; Bernoulia flammea Oliver can be pollinated by birds but produces large numbers of flowers in conspicuous panicles; Calophrllum brasiliense Camb. and Dialium guirancense (Aubl.) Sandwith are insect pollinated but not closely associated with a single vector (promiscuously pollinated). It is significant, however, that even when a species is primarily insect or bird pollinated this does not preclude entry of the pollen into the sedimentary record. One feature of Cenozoic sediments from tropical regions, in contrast to those of temperate environments, is the rather common occurrence of pollen from entomophilous species. Pollen of the Hibiscus/Humper type, and other highly 
ornamented pollen exceeding 100-125u in size are not unusual in Tertiary tropical sediments. One explanation may be the 'out-washing' of pollen under the heavy rainfall of tropical environments. According to Germeraad et al. (1968, p. 206), "Studies of Recent tropical sediments have since shown that, in a humid environment at least, water transport may be of far greater quantitative importance than wind transport (Muller, 1959) ". Where the basin of deposition is in close proximity, pollen of entomophilous plants commonly enters the sedimentary record in tropical environments more frequently than under seasonal temperate conditions. Since many of the dominants and common associated genera in the Veracruz rain forest are not exclusively insect pollinated, and since pollen of this type does enter the fossil record in tropical regions, entomophily in itself cannot explain the exceptionally poor representation of rain forest genera in the Paraje Solo sediments.

A few non-dominant genera commonly associated with the rain forest are represented in the microflora (Allophlulus. ef. Astrocartum. ef. Hiraea. Mataba, and possibly Mrria identified as Eugenia/Mvrcia). Pollen of all but Mrrcia is present in only trace amounts $(<1 \%)$. Both in number of genera (dominants and associates) and amounts of pollen the Deciduous Forest, presently removed by $1000 \mathrm{~m}$ elevation at minimum from the depositional basin, is better represented than the Tropical Rain Forest which grows marginal to the basin. These data suggest the Tropical Rain Forest was not a prominant component of upper Miocene vegetation in Veracruz and there is other corroborating evidence.

Pollen grains of Pice have been found in 5 samples distributed among 3 sities of the Paraje Solo Formation. The genus does not occur in southern Mexico at present, and is found only at high elevations $(2300-3200 \mathrm{~m})$ in Coahuila, Durango and Nuevo León $(P$. mexirana Martínez, P. chihuahuana Martínez; Gordon, 1968). The presence of spruce $1000 \mathrm{~km}$ south of its present range, through $8^{\prime \prime}$ of latitude, clearly argues for cooler climates in southeastern Mexico during Mio-Pliocene times. The current studies of González-Quintero on Miocene deposits in Mexico are of interest and preliminary results show the presence of Pices and the virtual absence of the rain forest also in Chiapas.

Several genera characteristic of temperate communities (viz., the oak-Liquidambar forest) are occasionally found scattered in the Tropical Rain Forest of Veracruz (Podocarpus. Mvrica). These have been interpreted as relicts of former cool periods and Sarukhan (Pers. Comm., 1974) suggests a lower annual mean temperature of $3.4^{\circ} \mathrm{C}$ would account for the ecological anomalies of the lowland forests of Veracruz.

An array of new independent evidence argues for cooler temperatures in southeastern Mexico during the late Cenozoic: (a) poor representation of the Tropical Raín Forest in upper Miocene sediments deposited in lowland environments, (b) presence of spruce pollen int Miocene deposits of Veracruz and Chiapas, (c) substantial representation of the present mid-altitude deciduous forest in the Paraje Solo lignites, suggesting a lowering of ecotones bringing the oak-Liquidambar forest in closer proximity to the depositional 
basin, and (d) presence of upland temperate elements as relicts in the modern lowland tropical forest. Sarukhan (Pers. Comm., 1974) notes that disaggregation of the Tropical Rain Forest through lower temperatures would favor expansion of the lowland warm-oak community (e.g., Quercus oleoides Cham. \& Schl.). This suggestion is consistent with high percentages of oak pollen (30-34\%) at Site 6, considerably greater than could be contributed by Quercus from the high altitude pine-oak or mid-altitude oak-Liquidambar forests.

These data demonstrate that although elements of the Tropical Rain Forest were present in Veracruz in the upper Miocene (Allophslus. of. Astrocartum. Matasba. of. Hirae'a. and possibly Wrria and Terminalia) they were not coalesced into the well-defined extensive association of recent time. If the rain forest was absent or poorly developed in Veracruz during the Mio-Pliocene, it is interesting to consider the age of this formation so frequently characterized as stable and of great antiquity. The lower temperatures apparent in Veracruz during the Mio-Pliocene were early stages in a climatic deterioration eventually culminating in the Pleistocene glaciations. If these lower temperatures were, at least in part, responsible for poor definition of the rain forest, it is difficult to envision any sustained period between the Mio-Pliocene and end of the glaciations when the tropical elements could coalesce into a relatively permanent association of modern aspect (Flint, 1971, p. 422). This raises the intriguing possibility that the modern Tropical Rain Forest in Veracruz may be of post-glacial origin of less than 11.000 vears.

Several models are available to explain species diversity in tropical environments. Some (Ashton, 1969) assume an ancient stable vegetation where new genotypes may persist, while others (Vuilleumier, 1971; Haffer, 1970; Vanzolini, 1973; Vanzolini and Williams, 1970) require a dynamic community experiencing new habitats and selective pressures. Evidence from modern and Quaternary biotas of the Amazon Basin suggests the Tropical Rain Forest has recently undergone considerable alteration in range and composition. The evidence from Veracruz demonstrates this dynamic aspect has characterized the rain forest, near its northern limits, since at least since Mio-Pliocene times.

\section{SUMMARY}

Palvnological studies of upper Miocene deposits, Veracruz, reveal the Tropical Rain Forest absent or poorly developed. Presence of spruce pollen indicates lower temperatures mav have prevented coalescence of tropical elements into the modern rain forest until post-glacial times. The data is consistent with recent speciation models based on fluctuating equatorial environments and dynamic rain forest vegetation. 


\section{GRAHAM, THE TROPICAL RAIN FOREST NEAR ITS NORTHERN LIMITS}

\section{RESUMEN}

Estudios palinológieos de depósilos del Mioceno superior de Veracruze revelan una ausenedia o escaso desarrollo de la selva alta perennifolia. La preseneda de polen de Pireee indiea bajas temperaturas que debieron haber impedido la coaleseencia de elementos repicales para configurar a una sele a húmeda moderna, lo cual ocurrió, hasta los períodos posteglariares. La informarión presentada es consistente con los modelos recientes de

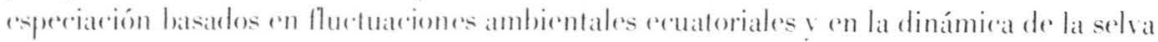
alla peremnifoliat.

\section{BIBLIOC;RAPHY}

ASHTON. P. S. 1969. Speciation among tropical forest trees: some deductions in the

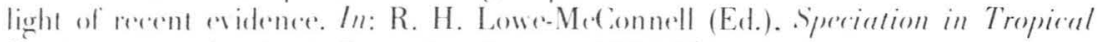
Eimironments. Academic Press. London. pp. 15.5-196.

B\RTI.ETT. A. and E.S. BARCHO(ORN. 1973. Phy togeographic history of the Isthmus of Panama during the past 12.000 vears (A histors of regetation. climate. and

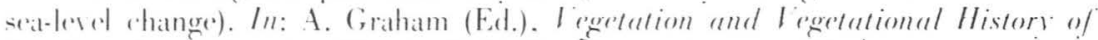
Northern Latin America. Elsevier Publ. Co., Amsterdam, pp. 203-299.

BRIF(,ER. F. (;. 1969. Patterns of asolutionals and geographical distribution in Veotropical orehids. In: R. H. Lowe-Meconnell (Ed.). Spercialion in Tropical Eintiromments. Academic Press. London. pp. 197.217.

(aRVER. F. J. H. 1958. The molution of tropical forest. In: J. Huxley. et al.. (Edrs.). Eirolution as "Proress. Allen and Inn in. London. pu. 34-46.

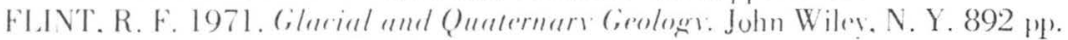

GERMERAAD, J. H., C. A. HOPPING, and J. MULLER. 1968. Palynology of Tertiary

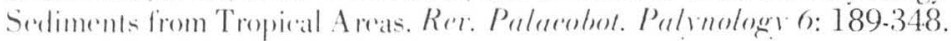

(;)MEZ.P()MPA. A. 1973. Eiologr of the regetation of Verarruz. In: A. Craham (Ed.),

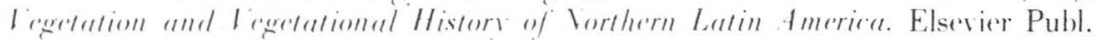
(o.e. Amsterdam. pp. 73-148.

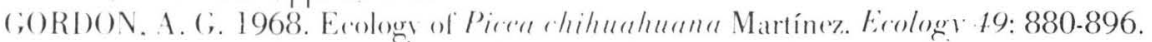
H AFFER. J. 1970. Coologic-ellimatic history and zoogeographic significance of the Urara region in northwestern Colombia. Caldilesin 10: 603-636.

VILLER. J. 1959. Palsnologs of Recent Orinowe delta and shelf sediments. Vicropuleontologer $5:$ : 1.32 .

RICHARDS. P. W. 1964. The Tropical Ruin Forest. Cambridge Unir. Press. London, 1.50 pl.

VAV DER HAMMEN. T. and E. GONZALEZ. 1960. Upper Pleistocene and Holocene climate and Vegetation of the "Sabana de Bogota" (Colombia. South America). Leridse (icol. Mededel. 2.5:261-315. 
VANZ()LINI, P. E. 1973. Paleoclimates, relief, and species multiplication in equatorial forests. In: B. Meggers, et al.. (Edrs). Tropical Forest Eirosistems in Africa and South Ameriea: 1 Comparatire Rerien: Smithsonian Inst. Press, Washington, D. C. Pl. $25.5-258$.

VAVZOLINI. P. E. and E. E. WILLIAMS. 1970. South American Anoles: the geographic differentiation and evolution of the Anolis chrosolepis species group (Sauria. Iguanidae). Ary. Zool. S. Paulo 19:1-240.

VUILLELMIER. B. 1971. Pleistocene changes in the fauna and flora of South America. Siriene 173:771-780. 


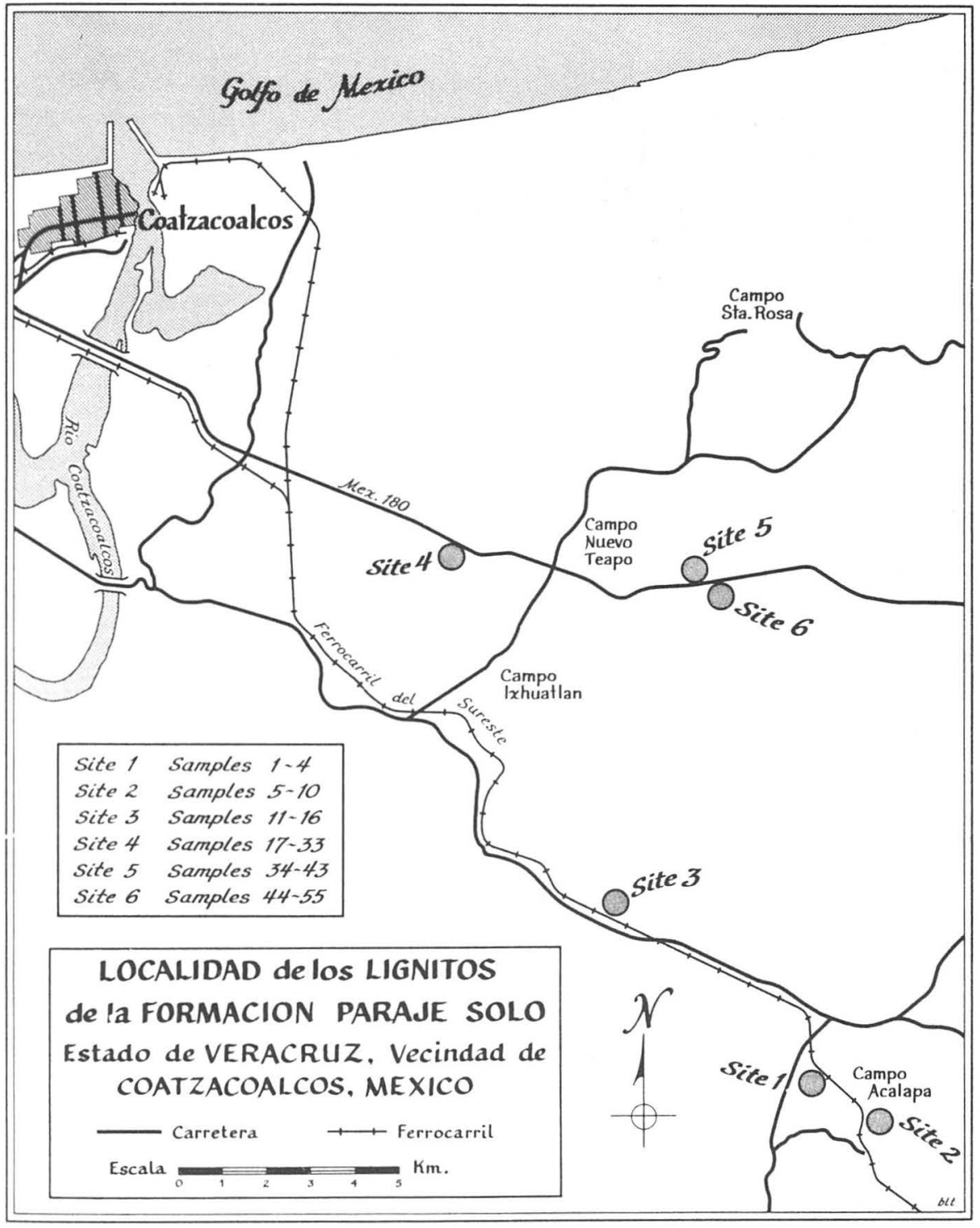

